\title{
Imaginario político colonial: las castas, una lectura para los registros parroquiales, matrículas y padrones de "Chile" (1680-1835)
}

Alejandra Araya Espinoza

Universidad de Chile alaraya@u.uchile.cl

Recibido: marzo de 2014

Aprobado: noviembre de 2014

Resumen: La historia social en la década de 1960 "redescubrió" los materiales predilectos de los genealogistas: registros parroquiales y "censales". Desde la década de 1990 esta documentación ha sido central para estudiar la sociedad colonial respecto de lo que se ha llamado "configuración socio-racial" o "clasificaciones socio-étnicas". En este trabajo se los comprende como prácticas coloniales, es decir, de reescritura sobre realidades pre-existentes y conformación y consolidación, en el acto de registrar, de una realidad nueva, desde el campo de la historia de las mentalidades comprendiendo la práctica de denominar, rotular y clasificar como formas de construcción de conocimiento, esquemas de representación e imaginarios políticos.

Palabras claves: castas, imaginario político, sociedad colonial, historia de las mentalidades.

\section{Colonial political imagination: caste, a reading for the parish records, license plates and patterns of "Chile"(1680-1835)}

Abstract: The social history in the 60's decade "re-discovered" the favorite tools of genealogists: parochial and census registry. Since de 90's decade, this documentation has been essential to study the colonial society in respect of what has been called "social-racial configuration" or "social-ethnic classifications". In this work these are understood as colonial practices, meaning, re-writings of pre-existing re-

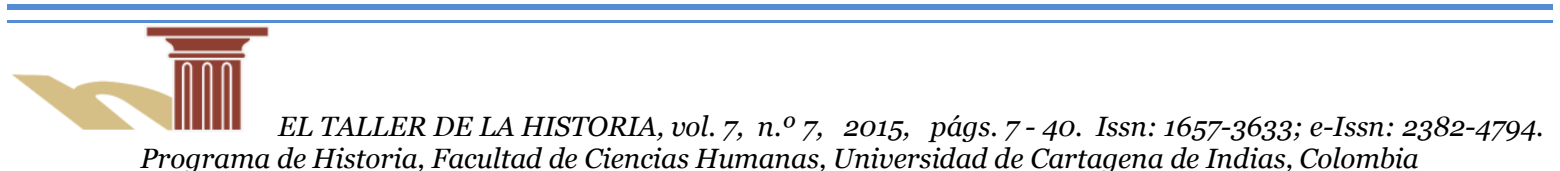


alities and conformation and consolidation, in the act of registering, of a new reality, from the field of history of mentalities, understanding the practice of naming, labeling and classification as knowledge construction forms, representation schemes and political imaginary.

\section{Presentación}

Este texto deriva de un proyecto de investigación de tres años en torno a los conceptos de casta y plebe, situándolos dentro de régimen imaginario para una realidad nueva: la sociedad colonial americana. ${ }^{1}$ Se trabajó con documentación de diversa naturaleza: crónicas, historias naturales, casos judiciales, libros parroquiales "chilenos" y "limeños", diccionarios de época y repertorios léxicos, pinturas como los llamados cuadros de castas, novelas del siglo XIX y del XX, documentación administrativa contenida en el Archivo General de Indias y el Archivo Nacional del Perú, matrículas y padrones de población. La lectura cruzada de todos ellos sustenta gran parte de los artículos generados por el proyecto a los cuales me remitiré de manera frecuente en este texto. En el proyecto me preguntaba por qué se los denominó de tal manera, por qué no fueron simplemente pobres, o simplemente plebe, y por qué castas. La respuesta puede ser obvia: porque no eran simplemente aquello, y por ello todavía queda trabajo por hacer para sistematizar los contenidos simbólicos de la estructura de las sociedades coloniales y mucho por hacer respecto de identificar, caracterizar y reconstruir las historias personales de los sujetos asociados a dichos conceptos e inscribir su lugar en nuestra historia colectiva e identidades individuales. ${ }^{2}$

\footnotetext{
${ }^{1}$ Proyecto Fondecyt 1080096: Imaginario socio político colonial: castas y plebe en Chile 1650-1800 (ejecutado entre los años 2008 y 2010). Investigadora responsable Alejandra Araya Espinoza, Ximena Azúa Co-investigadora. Mis agradecimientos a los ayudantes Natalie Guerra y Tomás Catepillán.

2 En tanto historia de las mentalidades este trabajo tiene sustentos teóricos antropológicos que se citarán en su lugar, pero quiero anotar que tiene coincidencias en sus temas con lo planteado por Carmen Bernand en aunque difiere radicalmente en sus interpretaciones por adoptar ella una situación cultural y de mentalidad -las denominaciones sobre las castas- como una situación cultural, la hibridez, dentro de la cuestión de la identidad individual de los sujetos. Carmen Bernand, "Híbridos en Hispanoamérica. Un enfoque antropológico de un proceso histórico", en Guillaume Boccara y Sylvia Galindo (eds.), Lógicas mestizas, Temuco-Chile, Instituto de Estudios Indígenas Universidad de la Frontera, 1999, pp.61-84.
} 
La historia social desde las décadas de 1950 en adelante "redescubrió" los materiales predilectos de los genealogistas: registros parroquiales y "censales". Desde la década de 1990 esta documentación ha sido central para estudiar la sociedad colonial respecto de lo que se ha llamado "configuración socio-racial"3 o "clasificaciones socio-étnicas". ${ }^{4} \mathrm{Mi}$ perspectiva pretende llamar la atención respecto de ellos como prácticas coloniales, es decir, de reescritura sobre realidades preexistentes y conformación y consolidación, en el acto de registrar, de una realidad nueva. Como también insertarlos dentro del campo de la historia de las mentalidades comprendiendo la práctica de denominar, rotular y clasificar como formas de construcción de conocimiento, esquemas de representación e imaginarios políti$\cos .^{5}$

Parafraseando a Rolando Mellafe respecto del marcador "edad" en el periodo colonial, podemos decir algo similar respecto de la conformación de las denominaciones de castas como experiencia cultural de la colonización: "que resulta luego de prolongados choques, fricciones y combinaciones de culturas con orígenes y sentidos totalmente distintos". ${ }^{6}$ Siguiendo al mismo historiador, en tanto cultor de la demografía histórica y la historia de las mentalidades y sus nuevas metodologías en la segunda mitad del siglo xx, no se debe perder de vista que todo imperio debe mantener un estricto control sobre sus recursos materiales y humanos y que de ellos derivan gran parte de la documentación que producen:

esta regla general quizás se cumplió más ampliamente en el caso de las posesiones españolas en el Nuevo Mundo -dice Mellafe- ya que, por lo menos en el

\footnotetext{
${ }^{3}$ Para una revisión actualizada del tema véase Sergio Paolo Solano, "Padrones de población e historiografía sobre la configuración socio-racial hispanoamericana del siglo XVıII", en El Taller de la Historia vol.5, n. ${ }^{\circ}$, Cartagena, Universidad de Cartagena de Indias, 2013, pp.125-177.

${ }^{4}$ Lorena Rodríguez, "Repensando las clasificaciones socio-étnicas del siglo XVIII. Indios, mestizos y españoles al sur del valle Calchaquí (Argentina)", en Fronteras de la Historia vol.13, n. ${ }^{\circ}$, Bogotá, ICANH, 2008, pp.305-323.

${ }^{5}$ Véase Alejandra Araya Espinoza, "Registrar a la plebe o el color de las castas: 'Calidad', 'clase' y 'casta' en la matrícula de Alday (Chile, siglo XVIII)", en Alejandra Araya y Jaime Valenzuela (eds.), Denominaciones, clasificaciones e identidades en América colonial, Santiago, Fondo de Publicaciones Americanistas Universidad de Chile/Pontificia Universidad Católica de Chile/RIL Editores, 2010, pp.331-361.

${ }^{6}$ Rolando Mellafe y Lorena Loyola, "El tiempo, la edad, la vejez", en Rolando Mellafe y Lorena Loyola, La memoria de América colonial, Santiago, Editorial Universitaria, 1994, p.40.
}

Dossier: Cuestionando las fuentes de archivos: padrones de población, familias y sociedades coloniales en Iberoamérica, ss. XVIII-XIX 
siglo XVI, su Imperio fue constantemente expansivo y estaba imbuido de un profundo afán evangelizador... Pocos pueblos conquistadores tuvieron más claro que los españoles el aserto de que para establecer una perfecta relación de dominio sobre una sociedad es necesario previamente conocerla en profundidad. ${ }^{7}$

En este ensayo presentaré en particular una lectura de los documentos conocidos como matrículas o padrones desde el contenido de su forma y para Chile aunque inserto dentro de tradiciones y prácticas de escritura burocrática y de control colonial compartidas en tanto dominio del imperio español. Desde dicha práctica política presentaré los principales resultados en cuanto al concepto de "castas" y su particularidad americana.

\section{Castas: la mejor representación posible de lo desconocido}

En cuanto al término castas he sostenido que conceptualmente forma parte de las configuraciones discursivas insertas en los géneros de la descripción y de la historia natural, utilizado de forma recurrente por los llamados cronistas de indias y autoridades provenientes de círculos intelectuales y de formación académica, tanto jurídica como científica. De entre ellos, fue clave para el proyecto el Inca Garcilaso de la Vega por cuanto señala con claridad el gesto de nombrar como acto mismo de constitución de una realidad y, por lo tanto, de inscribir en un mundo social una forma de decir sobre lo social. ${ }^{8}$ En el libro IX, el capítulo XXXI titulado "Nombres nuevos para nombrar diversas generaciones" se refiere al gesto particular de nombrar a las naciones de españoles y negros "que tampoco los había antes en aquella tierra", para diferenciarse de los "naturales" de Indias así como de los de sus mismas naciones que nacían "allá” y no "acá” [España]. Concluye el capítulo con una

\footnotetext{
7 Rolando Mellafe, "Demografía histórica de América Latina. Fuentes y métodos", en Rolando Mellafe, Historia social de Chile y América. Sugerencias y aproximaciones, Santiago, Editorial Universitaria, 1986, p.146.

8 Alejandra Araya Espinoza, “¿Castas o razas?: imaginario sociopolítico y cuerpos mezclados en la América colonial. Una propuesta desde los cuadros de castas”, en Hilderman Cardona y Zandra Pedraza (comps.), Al otro lado del cuerpo. Estudios biopolíticos en América Latina, Bogotá, Universidad de los Andes/Universidad de Medellín, 2014, pp.53-73.
} 
afirmación fundamental respecto del nombrar como práctica colonial: "Todos estos nombres $-\mathrm{y}$ otros que por excusar hastío dejamos de decir- se han inventado en mi tierra para nombrar las generaciones que ha habido después que los españoles fueron a ella. Y podemos decir que ellos los llevaron con las demás cosas que no había antes". 9

La pregunta por la naturaleza o el lugar de nacimiento se desplazaba en el siglo XVII desde el ámbito de la nación, justamente definida como lugar de nacimiento, al de producto de la tierra (paños de la tierra, carneros de la tierra, gente de la tierra, etc.). ${ }^{10}$ Considero los conceptos de castas y plebe como los símbolos constitutivos del imaginario político de la nueva sociedad colonial americana. Como imaginario político asumo la definición de Juan Amador Bech, el que a su vez se sustenta en los planteamientos Gilbert Durand respecto del concepto de imaginario, dice Amador: "A todo el conjunto de imágenes, metáforas, intuiciones, deseos, y proyecciones, conceptos y enunciados que sirven para interpretar y explicar la vida política le llamaremos imaginario político [...] Al interior de ese intercambio discursivo se constituye el imaginario político: a través de los procesos de comunicación e interacción sociales que suponen el intercambio de discursos e imágenes". ${ }^{11}$ Sobre quién y cómo se debe ejercer el dominio, qué privilegios y dignidades tienen en la vida política de un imperio, por lo tanto, resolver qué tipo de súbditos son los nacidos en las nuevas posesiones, es un gran asunto de la política indiana.

La relación entre teóricos del derecho indiano, autoridades políticas y agentes del poder colonizador en su versión burocrática y eclesiástica, se puede ejemplificar con las correspondencias entre la práctica del registro producidos por párrocos, en particular en la segunda mitad del siglo XvIII, y los dictámenes del destaca-

${ }^{9}$ Garcilaso de la Vega, Comentarios reales de los incas, ed. Carlos Araníbar, México, Fondo de Cultura Económica, 1991 [1609], tomo II, p.628.

10 Para un mejor desarrollo de la obra del Inca Garcilaso dentro de la historia natural véase Luis Millones, "Filosofía e historia natural en el Inca Garcilaso", Biblioteca Virtual Miguel de Cervantes, consultado en línea el 23/12/2010. Sobre naturaleza y el concepto de las naciones Carmen Bernand, "Híbridos en Hispanoamérica. Un enfoque antropológico de un proceso histórico", pp.68 y ss. También Fermín del Pino, "Historia natural y razas humanas en los 'cuadros de castas' hispanoamericanos, en Frutas y castas ilustradas, catálogo de la exposición Museo de Antropología, 25 de febrero-29 de agosto de 2004, Madrid, Ministerio de Educación, Cultura y Deporte, 2004, pp.47-66.

11 Julio Amador Bech, Las raíces mitológicas del imaginario político, México, Universidad Nacional Autónoma de México/Miguel Ángel Porrúa, 2004, pp.226-227.

Dossier: Cuestionando las fuentes de archivos: padrones de población, familias y sociedades coloniales en Iberoamérica, ss. XVIII-XIX 
do jurista Juan de Solórzano Pereira ${ }^{12}$ en un texto de significativo título: Política Indiana, una de sus obras más destacadas, calificada por él como "Obra de sumo trabajo", pues pretendía ser de "igual importancia, y utilidad no solo para los de las Provincias de las Indias, sino de las de España, y otras Naciones (de cualquier profesión que sean) por la gran variedad de cosas que comprehende, adornada de todas las letras, y escrita con el método, claridad, y lenguaje, que por ella parecerá". Esta afirmación es muy importante pues su carácter práctico y de servicio condensa lo que está en uso y sugiere lo que debe hacerse luego de resumir los debates que había habido al respecto desde el siglo XVI y lo que estaba en vigencia cuando salió la primera edición del texto en 1648. Las continuas reediciones del texto en el siglo XVIII avalan su aceptación como autoridad respecto de la cuestión de las Indias. En el Libro segundo de la Política Indiana en que se trata de la libertad, estado, y condiciones de los Indios y a qué servicios personales pueden ser compelidos por el bien público, encontramos el capítulo xxx titulado "De los criollos, mestizos, y mulatos de las Indias, y sus calidades, y condiciones: y si deben ser tenidos por Españoles? "[sic]. Repasemos un poco las connotaciones que tiene el lugar donde se inserta el tema, esto es, la libertad, estado y condición de los "indios" de un lado (con el objeto de definir el servicio personal al que podían ser compelidos), y del otro, la pregunta por la "calidad" y "condición" de criollos, mestizos y mulatos (en cuanto a ser reconocidos o no como "Españoles"), por lo tanto, si se eximían o no del servicio personal. La verdad, es mucho mejor leer directamente al autor que expone de manera brillante los argumentos, pero me permito destacar algunos puntos que permiten comprender los pilares de todas las discusiones sobre la "calidad" de es-

\footnotetext{
12 Juan Solórzano Pereyra (1575-1655). Nació en Madrid, en una familia con tradición en los estudios de Leyes, licenciatura que completó en la Universidad de Salamanca. El rey Felipe III de España le nombró oidor de Real Audiencia de Lima, en 1609 permaneciendo en la capital peruana dieciocho años. Nadie conocía, mejor que él, los problemas del gobierno de la América española a mediados del siglo XVII y nadie los expuso con mayor claridad y erudición en su monumental Política indiana, obra que cumple la función de transmitir la cultura jurídica de su tiempo cuya primera edición es de 1648. En ella cita a numerosos juristas, pero también a teólogos, padres de la Iglesia, humanistas, cronistas de Indias, etc. Sobre el autor véase la interesante reseña de Salvador Bernabéu Albert, "Juan de Solórzano y Pereira: De Indiarum Iure (Liber III: De retentione Indiarum), Madrid, Consejo Superior de Investigaciones Científicas, 2001", Nuevo Mundo Mundos Nuevos [En línea], Reseñas y ensayos historiográficos, Puesto en línea el 04 febrero 2005, consultado el 18 febrero 2015. URL: http://nuevomundo.revues.org/251.
} 
tas nuevas generaciones. En primer lugar, el que la calidad y la condición la define "el origen natural de los padres", por ejemplo, los "Españoles" definen la "condición" de los hijos que hayan tenido en mujeres indias, es decir su mayor o menor libertad del servicio personal, en caso de ser reconocidos por ellos y que, los criollos, debían ser reconocidos como iguales, "Españoles de Indias", por nacidos en ellas, lo eran verdaderamente porque dichas

[...] provincias son como auctuarios de las de España, y accesoriamente unidas e incorporadas a ellas, como expresamente lo tienen declarado muchas Cédulas Reales", a lo que él añade, para rebatir todos los supuestos de la degeneración de tal calidad en estas tierras, la tesis de que "la cosa que se agrega a otra, toma, y sigue siempre, sus calidades, como lo prueba muy a la larga Tyberio Deciano, y que estos hijos de Españoles vienen a ser, y son, oriundos de España, aunque los haya en partes tan remotas de ellas, y por consiguiente, por otras reglas del mismo derecho, no siguen el domicilio, sino el origen natural de sus Padres, del cual todas las cosas se suelen reducir, y referir de ordinario, reteniendo y conservando la calidad que de él en ellas deriva, según la doctrina de otras leyes, y las elegantes palabras de Casiodoro. ${ }^{13}$

Pasando al caso de Mestizos y Mulatos "lo que se me ofrece decir es, que tomaron el nombre Mestizos por la mixtura de sangre, y Naciones, que se juntó a engendrarlos, por donde los Latinos los llamaron Varios, ${ }^{14}$ e Híbridas, según Paleoto y otros Autores", y en cuanto a los mulatos, nótese que "por la misma razón deben comprehenderse en el nombre general de Mestizos, tomaron éste nombre en particular, cuando son hijos de negra, o hombre blanco o al revés, por tenerse esta mezcla por más fea, y extraordinaria, y dar a entender, con tal nombre, que le compa-

\footnotetext{
${ }^{13}$ Juan de Solórzano Pereira, Política Indiana, Dividida en seis libros, en los cuales con gran distinción; y estudio se trata, y se resuelve todo lo tocante al descubrimiento, Madrid, Gabriel Ramírez, 1736-39, Lib.II, cap.XXX, 3, p.219.

14 Diverso, multiforme, diferente. Henríquez, 1679. Consultado en http://buscon.rae.es/ntlle/SrvltGUIMenuNtlle?cmd=Lema\&sec=1.4.o.o.o.
}

Dossier: Cuestionando las fuentes de archivos: padrones de población, familias y sociedades coloniales en Iberoamérica, ss. XVIII-XIX 
ran a la naturaleza del mulo: como lo notó bien D. Sebastián de Covarrubias,* de cuya generación y sus mezclas, es digno de leerse lo que trae Plinio". ${ }^{15}$

Luego el autor agrega el gran "pero" para esta situación teórica de igualdad de origen por naturaleza de los padres, el nacimiento por matrimonio legítimo: "Y si estos hombres hubiesen nacido de legítimo matrimonio, y no se hallase en ellos otro vicio, ó defecto que lo impidiese, tenerse, y contarse podrán, y deberían por Ciudadanos de dichas Provincias, y ser admitidos á las honras, y oficios de ellas, como lo resuelven Victoria y Zapata: y a eso puedo creer, que miraron algunas Cédulas Reales, que permiten ser ordenados los Mestizos, y las Mestizas recibidas por Monjas, y admitidos a Escribanías, y Regimientos”. El mismo autor dice que hubo pocos "españoles de honra" que se que se casasen con indias o negras, entonces fue común que sobre los descendientes cayese la "mancha del color vario". ${ }^{16} \mathrm{El}$ "mal nacimiento" era una tacha y sus poseedores debían esta bajo cuidado conveniente "para que hombres de tales mezclas, y viciosos por la mayor parte no ocasionen daños, y alteraciones en el Reyno [...] y más se consiente vivir ociosos”. Aquí opera la connotación de mestizo como mixto, seguramente también aceptando lo que Sebastián de Covarrubias consignaba en 1611: "el que es engendrado de diversas especies de animales, del verbo misceo, es, por mesclarse". ${ }^{17} \mathrm{El}$ fenómeno de estos cruces se está leyendo como reunión de cosas diversas, una mescolanza. El mismo autor citado aporta los elementos políticos que hacen peligrosa esta situación: "Mezclarse los linajes, cuando se confunden unos con otros, que no son de una misma calidad, y decimos estar una cosa sin mezcla cuando no está pura". ${ }^{18}$ Tanto la condición de la mezcla, en tanto situación confusa y alterada, políticamente sitúa a los mestizos/mixtos en un lugar menos estable que el que la historia natural pudiera asignarle y que, en el terreno de la política, claramente los integró a un problema de control social que en el siglo XviII se tradujo en una ideología sobre las

\footnotetext{
* Está citando efectivamente Sebastián de Covarrubias, 1995 [1611], Tesoro de la lengua castellana o española, ed. Felipe C. R. Maldonado, Madrid, Castalia, p.768. En NTTLE de la Rae no aparece este lema.

15 Juan de Solórzano Pereira, Política Indiana, 3, p.220.

16 Juan de Solórzano Pereira, Política Indiana, pp.220-221.

17 Sebastián de Covarrubias, 1995 [1611], Tesoro de la lengua castellana o española, Felipe C. R. Maldonado (ed.), Madrid, Castalia, p.751.
}

${ }^{18}$ Sebastián de Covarrubias, 1995 [1611], Tesoro de la lengua castellana o española, p.752.

Dossier: Cuestionando las fuentes de archivos: padrones de población, familias y sociedades coloniales en Iberoamérica, ss. XVIII-XIX 
castas y la plebe como población naturalmente peligrosa por mal de origen y, claro, sospecha permanente respecto de él. ${ }^{19}$

Solórzano también nos muestra que se van haciendo asociando ideológicas entre el origen y la pureza, generándose entonces una suerte de medición de la mejor o peor mezcla de una forma casi alquímica, estabilidad que sólo podía asegurar el conocimiento y certeza de los padres unidos legítimamente: "Los Mestizos es la mejor mezcla, que hay en Indias, y son los hijos de los Españoles, e Indias; y también lo serán si un Indio se casase con una Española, aunque esto sucede rara vez", ${ }^{20}$ los nacidos de legítimo matrimonio estarán acogidos a todas las leyes. Los Indios, por otro lado, nacidos de legítimo matrimonio debían ser más favorecidos que los Mestizos y Mulatos ilegítimos "de tan malas castas, razas, y condiciones contra la regla que nos enseña, que no debe ser más privilegiada la luxuria, que la castidad". ${ }^{21}$ Luego de abordar asuntos relacionados con el debido pago de tributos de tales sujetos, recuerda al lector que se "ordena, que se solicite que los Negros casen con Negras, porque de las dos mezclas pueden salir peores". 22

Casta opera entonces en su acepción más antigua: "casta buen linaje" (Nebrija, 1495). Tal como he mostrado, lo polémico es definir qué es ese buen linaje, pues ya a mediados del siglo XVII como demuestra Solórzano se pone en duda la calidad de los descendientes procreados en estas tierras y de allí su defensa del buen origen de los criollos, como también de los mestizos, en tanto se pueda probar que son nacidos de legítima unión. Nuevamente es Covarrubias el que proporciona los elementos que simbólicos que se van estructurando dentro del campo del orden de las castas, pues recuerda que casta es tanto linaje como pureza: "vale linaje noble, y castizo, el que es de buena línea y descendencia, no embargante que decimos

\footnotetext{
${ }^{19}$ Las relaciones el concepto de mestizo y la mixtura desde la tradición de los tintes y la alquimia está Alejandra Araya Espinoza, “¿Castas o razas?: imaginario sociopolítico y cuerpos mezclados en la América colonial. Una propuesta desde los cuadros de castas”, pp.53-73. La relación entre mestizos y plebe he dedicado variados trabajos, siendo el más clásico Alejandra Araya, Ociosos, vagabundos y malentretenidos en Chile colonial, Santiago, Centro de Investigaciones Diego Barros Arana/LOM, 1999.

20 Juan de Solórzano Pereira, Política Indiana, Lib.II, cap.XXX, 32-33, p.222.

21 Juan de Solórzano Pereira, Política Indiana, Lib. II, cap. XXX, 29, p.222.

22 Juan de Solórzano Pereira, Política Indiana, Lib. II, cap. XXX, 42, p.222.
}

Dossier: Cuestionando las fuentes de archivos: padrones de población, familias y sociedades coloniales en Iberoamérica, ss. XVIII-XIX 
es de buena casta y mala casta". ${ }^{23}$ Ya en el siglo XvIII, el Diccionario de Autoridades en su edición de 1729, recoge la nueva norma social, es decir, el origen conocidos de los padres al decir de Casta, "generación y linaje que viene de Padres conocidos". No obstante, lo que permite seguir comprendiendo el lugar de las nuevas generaciones en un campo simbólico es la connotación de confusión de una mezcla, que aumenta si no hemos distinguido los componentes de origen, la pureza comprendida como claro y distinto en este caso, como la operación visual de representación que aportan los cuadros de castas. En la segunda acepción, de la misma edición, se ratifica con lo que se señala para castas aplicado al "linaje de los caballos, toros y otros animales porque vienen de padres conocidos por su lealtad, fiereza u otra circunstancia que los hace señalados y particulares”. ${ }^{24}$ En la edición de 1780, se agrega que casta, es lo mismo que "especie, o calidad de alguna cosa". ${ }^{25}$

Sumemos a otro autor, en 1776, el jesuita Ignacio de Molina contemporáneo de los párrocos que estaban elaborando la Matrícula del Obispado de Santiago de 1778, y ya expulso escribiendo en Bolonia, para mostrar cómo estamos en presencia de la conformación de un imaginario político operante y estructurado desde múltiples discursos que se espejean entre sí, yendo de la interacción social a la configuración de una epistemología sobre el orden social en tanto natural, elementos que, justamente, irán siendo impugnados en la gran trasformación de las mentalidades que, en ese mismo siglo se está gestando: pasar de la desigualdad natural a la igualdad natural. Molina quería que todos los lectores entendieran las descripciones sobre la naturaleza americana, explicando sólo algunos atributos para caracterizar los objetos y omitiendo aquellas comunes a todo el género. En el Compendio también apela los saberes y criterios locales, que también operan-por ejemplo- en las leyendas de los cuadros de castas producidos en México o en el Perú. Veamos el caso de una especie de oca de las islas de Chiloé a la que nombra Anas Hybrida (recordar la explicación de Solórzano sobre los mestizos como híbridos citando a Plinio) y cuya particularidad era la diferencia de color entre macho y hembra, él de blancas plumas y ella de negras: "esta total diferencia me resolvió a señalar esta

\footnotetext{
${ }^{23}$ Sebastián de Covarrubias, 1995 [1611], Tesoro de la lengua castellana o española, p.282.

${ }^{24} \mathrm{RAE}, 1729$. Consultado en http://ntlle.rae.es/ntlle/SrvltGUIMenuNtlle?cmd=Lema\&sec=1.4.o.o.o, 10 febrero 2015.

${ }^{25}$ RAE, 1729. Consultado en http://ntlle.rae.es/ntlle/SrvltGUIMenuNtlle?cmd=Lema\&sec=1.4.o.o.o, 10 de febrero 2015.
}

Dossier: Cuestionando las fuentes de archivos: padrones de población, familias y sociedades coloniales en Iberoamérica, ss. XVIII-XIX 
especie con el epíteto de hibryda, ó mulata, como descendiente de un blanco y de una negra”. ${ }^{26}$ Para que sea comprensible por el común explica con el ejemplo social, mulata: descendiente de blanco y negra.

El trabajo de Molina también es interesante para comprender las complejas relaciones entre el concepto de casta y el de raza, quizás, siempre hubo sutiles opciones entre uno y otro concepto. Sin embargo, como señala Carlos López Beltrán respecto de los saberes médicos y de la ciencia, se debe evitar hacer un traslado anacrónico de las "preocupaciones y configuraciones descriptivas pertenecientes a esquemas posteriores" como la "reproyección de la noción decimonónica de raza, de regímenes raciales, de sociedades racialmente conformadas, lo que ha generado desencantos y malas lecturas". ${ }^{27}$ En la obra de Molina el término raza sólo aparece para hablar de los perros y los caballos, ambos son para él un buen tema para explicitar el objetivo de su obra, "desmentir" las afirmaciones sobre la naturaleza americana que circulaban en otros textos:

Nada ha sido tan pernicioso a la Historia Natural de la América como el abuso que se ha hecho, y se continua haciendo de la nomenclatura [el destacado es míos]; de esto se han derivado los voluntarios sistemas de degradación de los cuadrúpedos en aquel inmenso continente; y de aquí proceden los ciervos pequeños, los osos pequeños, \&c. Que se le alegan y citan a favor de aquellos sistemas, y los quales no convienen con la especie a que se supone pertenecen nada más que en el nombre abusivo que les pusieron algunos historiadores de poca observación que se dejaron engañar de las apariencias superficiales de las formas y las figuras. ${ }^{28}$

En el caso de los caballos, caracterizados en Chile por su paso, también vemos el debate sobre la naturaleza de estas tierras, pues no se sabía si era adquirido en el nuevo territorio o por "inclinación o raza" (mismo asunto que con los descendien-

\footnotetext{
${ }^{26}$ Juan Ignacio Molina, Compendio de la historia civil del Reyno de Chile, parte primera, traducida al español, y aumentada con varias notas por Nicolás de la Cruz y Bahamonde, Madrid, Imprenta de Sancha, 1788. Edición facsimilar Biblioteca del Bicentenario, Santiago, Pehuén Ltda., 2000, p.268. La primera edición es de 1776, publicada sin señas del autor y en italiano en situación de exilio.

${ }^{27}$ Carlos López Beltrán, "Sangre y temperamento. Pureza y mestizajes en las sociedades de castas americanas”, en Frida Gorbuch y Carlos López (eds.), Saberes locales: ensayos sobre historia de la ciencia en América Latina, Michoacán, El Colegio de Michoacán, 2008, p.308.
}

${ }^{28}$ Juan Ignacio Molina, Compendio de la historia civil del Reyno de Chile, parte segunda, p.303.

Dossier: Cuestionando las fuentes de archivos: padrones de población, familias y sociedades coloniales en Iberoamérica, ss. XVIII-XIX 
tes humanos)-pues todavía se veían en España muchos con esta propiedad- señalaba: "[...] sí diré que habiendo tenido mas cuidado allá [América] en conservar la casta, sin que mezclados los de ella con los puramente de trote, degenere, son incomparablemente muchos más perfectos aquellos que los de acá”, esta cualidad los hacía muy preciados como regalo en Lima, Quito y otros reinos "con cuyo motivo se han hecho castas en todos aquellos países, pero en ninguno prevalecen con la perfección que en Chile”. ${ }^{29}$

En el artículo "Registrar a la plebe o el color de las castas: "Calidad", "clase" y "casta" en la matrícula de Alday (Chile, siglo XVIII)", 30 sostengo que "Casta", "clase" y "calidad" organizan los protocolos de escritura de los llamados registros parroquiales y censales del siglo XVIII, desarrollando las implicancias que tiene decir que es una sociedad de calidades, no de clases en un sentido contemporáneo: "porque remite a un conjunto de propiedades inherentes a una cosa que permite apreciarla como igual, mejor o peor que las restantes de su especie, como también al estado de una persona, su naturaleza, edad y demás circunstancias y condiciones que se requieren para un cargo o dignidad. Todos estos elementos podían combinarse de distintas maneras y configurar el lugar social de un sujeto según su nobleza, autoridad, oficios y color". ${ }^{31}$

Esto quiere decir que es una sociedad de diferencias en torno a cualidades que se traducen en rótulos como "español", "indio", "negro", "mestizo", como nombres de las clases existentes dentro de una especie. La relación entre calidad, clase y castas, de acuerdo con las formas de organizar el registro en la matrícula de Alday, plantea que un gesto es el de distinguir, separando (calidad-clase) y otro el de distanciarse (calidad-casta). Para definir el rótulo que le corresponde a una persona, se recurre a un imaginario de las "castas" de tradición animal, pero no zoológica, sino que relacionada con la cría de ganados por lo que funciona bien para instalar el principio de las generaciones, es decir, de dónde procede el sujeto al cuál se va a

\footnotetext{
${ }^{29}$ Juan Ignacio Molina, Compendio de la historia civil del Reyno de Chile, parte segunda, p.368.

${ }^{30}$ Alejandra Araya Espinoza, "Registrar a la plebe o el color de las castas: 'Calidad', 'clase' y 'casta' en la matrícula de Alday (Chile, siglo XVIII)", pp.331-361.

${ }^{31}$ Alejandra Araya Espinoza, "Registrar a la plebe o el color de las castas: 'Calidad', 'clase' y 'casta' en la matrícula de Alday (Chile, siglo XVIII)", p.9.
}

Dossier: Cuestionando las fuentes de archivos: padrones de población, familias y sociedades coloniales en Iberoamérica, ss. XVIII-XIX 
rotular. De allí entonces la importancia de consignar la calidad de casta en las partidas de bautismo y matrimonio.

Me parece que los materiales producidos por la práctica política jurídica, administrativa o burocrática dan cuenta de que las "castas" operan como signo alegórico. Según Gilbert Durand, un signo que pierde su arbitrariedad teórica cuando remite a abstracciones tornándose la traducción concreta de una idea difícil de captar o expresar en forma simple "contiene siempre un elemento concreto o ejemplar del significado; es parcialmente adecuado" y por ello permite varias funciones semánticas semejantes que podemos encontrar en los repertorios de denominaciones que identifican a castas alegorías, emblema y metonimias (español-blanco, mestizo-mixto, negro-esclavo, mulato, grifo, no te entiendo, etc.).32 Los cuadros de castas, como objeto específico de representación, indicaría que "castas" se ha transformado en el siglo XVIII en un símbolo, todavía siguiendo a Durand, esto es, algo concreto pero inadecuado pues el significante y el significado "son totalmente abiertos: el significado es imposible de presentar y el signo sólo puede referirse a un sentido [recordemos que los cuadros de la década de 1760 en adelante introducen cartelas que definen las nomenclaturas], y no a una cosa sensible; es la mejor representación posible de lo desconocido". 33

\section{Matricular y censar: entre casta y plebe}

Revisemos entonces la operatividad de estos planteamientos desde un documento clave para Chile que era conocido como el único "censo" existente para el periodo colonial, el llamado Censo de Jáuregui. El documento utilizado por Carmagnani y Klein en 1965, existente en el Archivo General de Indias, fue trabajado por ellos sólo con las tablas resúmenes. ${ }^{34} \mathrm{El}$ cotejo del documento original con la bibliografía que hacía referencia a él desde la década de 1940 hasta el trabajo señalado, impuso

\footnotetext{
32 Para revisar las nomenclaturas asociadas a las castas en diversos repertorios coloniales véase Manuel Alvar, Léxico de mestizaje en Hispanoamérica, Madrid, Ediciones de Cultura Hispánica, 1987.

33 Gilbert Durand, La imaginación simbólica, Buenos Aires, Amorrortu Editores, 1971, p.23.

34 Marcello Carmagnani y Herbert Klein, "Demografía histórica: la población del Obispado de Santiago, 1777-1778”, Boletín de la Academia Chilena de la Historia n. ${ }^{\circ} 72$, Santiago, Academia Chilena de la Historia, 1965, pp.57-74.
}

Dossier: Cuestionando las fuentes de archivos: padrones de población, familias y sociedades coloniales en Iberoamérica, ss. XVIII-XIX 
una pequeña investigación casi policial para dilucidar la correspondencia entre lo que se llamaba "censo de Jáuregui" y el documento existente en el Archivo General de Indias. En otro trabajo detallo esta discusión, la que resumo: el censo de Jáuregui no existe en forma completa en los Archivos en Chile como tampoco en el de Indias; lo que fue trabajado en los años sesenta bajo ese nombre es una Matrícula parroquial mandada a realizar por el Obispo de Santiago, Manuel Alday. ${ }^{35}$ Las encuestas fueron recopiladas por quince párrocos diferentes que cubrieron doctrinas y corregimientos del Obispado de Santiago (Coquimbo por el norte, Maule por el Sur, incluyendo Mendoza y Cuyo al otro lado de la cordillera) entre 1777 y 1778. Veamos la importancia que puede tener considerar las características de los "géneros" documentales coloniales a la hora de convertirlos en datos de población y, en particular, si queremos considerarlos fuentes para estudiar la "configuración socioracial" de esta sociedad, digo yo, de castas.

La Matrícula es un padrón general de todas las ánimas del Obispado de Santiago. La reciente investigación sobre las matrículas para el Sagrario Metropolitano, parroquia principal de la ciudad de México, me permitieron confirmar esta calidad. El Sagrario Metropolitano de la ciudad de México conserva estos registros entre 1670 a 1816, con breves intervalos de años ausentes. Los investigadores a cargo de la edición facsimilar de los mismos los llaman 'padrones' de confesión y comunión o "cuarto libro" parroquial. ${ }^{36}$ Estos registros se exigieron en México desde el Concilio Primero Provincial Mexicano de 1555 y tenían por finalidad conocer cómo se cumplía con los sacramentos de la confesión y de la comunión por parte de todas y cada una de las almas.

En 1585, el Tercer Concilio Provincial Mexicano, incorpora esta dimensión señalando que, por medio de este registro, los curas regulares y seculares debían conocer "individualmente a sus ovejas, y sepan quiénes son sus fieles de uno y otro sexo que están encomendados a su cuidado paternal" ${ }^{37}$ de edades superiores a los

\footnotetext{
35 Manuel Alday Aspee, Decimoctavo obispo de Santiago de Chile, nombrado en 25 de noviembre de 1753; a cargo de la diócesis entre 1755 y 1788.

36 Óscar Mazín y Esteban Sánchez de Tagle (coords.), Los "padrones” de confesión y comunión de la parroquia del Sagrario Metropolitano de la ciudad de México, México, El Colegio de México/Red Columnaria, 2009.

37 Óscar Mazín y Esteban Sánchez de Tagle, Los "padrones" de confesión y comunión de la parroquia del Sagrario Metropolitano de la ciudad de México, p.21.
}

Dossier: Cuestionando las fuentes de archivos: padrones de población, familias y sociedades coloniales en Iberoamérica, ss. XVIII-XIX 
diez años, expresando el sexo al que pertenecían y "su calidad de españoles, mestizos o negros, y de los descendientes de estos últimos", 38 asentando sus nombres y cabezas de familia. Recordemos que calidad es la que dota al sujeto el origen natural de los padres. El registro parroquial por tanto, no sólo es el documento que da fe de los sacramentos, sino que del origen del sujeto tanto en su calidad de casta como es su legitimidad de nacimiento.

Comparando esta matrícula con padrones parroquiales similares para México y Perú, sostengo que las formas en que se registra son claves de los imaginarios políticos y sociales operantes en el extenso territorio americano porque registrar es una acción más que un trabajo burocrático: es el registro del recorrido físico del párroco por los barrios de su feligresía, es la huella de los criterios claros y distintos operativos en ese sujeto o sujetos (párroco, escribano) para organizar información según cómo entendía el ejercicio del poder en tanto administración de un territorio y unos habitantes, tales documentos nos introducen en las grafías mentales del territorio bajo control, sus habitantes y las diferentes escalas de observación puestas en juego al anotar nombres y números. ${ }^{39}$

En mi trabajo he seguido las anotaciones que hiciera Rolando Mellafe respecto de las fuentes y el método de una demografía histórica para América Latina haciendo una distinción entre documentación relativa a la población total de carácter pre-estadístico (visitas de la tierra y visitas generales, visitas de desagravio o circunstanciales, libros de tasas y tributos, visitas pastorales y matrículas de confesión) y los de una etapa proto-estadística (censos parciales, censos generales, censos de población infiel, informes de misiones y comandancias e informes de intendentes). ${ }^{40}$ Lo que puedo afirmar como resultado del proyecto, es que en este tipo de documentos registrar la calidad de casta (español, indio, mestizo, negros, etc.) no era algo recurrente, ni uniforme, ni formular, sino que dependía en gran parte de quién registraba. De esta forma, metodológicamente, es muy significativo detectar

38 Óscar Mazín y Esteban Sánchez de Tagle, Los "padrones" de confesión y comunión de la parroquia del Sagrario Metropolitano de la ciudad de México, p.15.

${ }^{39}$ Alejandra Araya Espinoza, "La Matrícula de Alday (1777-1778): imaginarios sociales y políticos en el siglo XVIII americano", América a debate. Revista de Ciencias Históricas y Sociales n. ${ }^{\circ} 16$, Morelia, Universidad de Michoacán, 2009, pp.11-33.

${ }^{40}$ Rolando Mellafe, "Demografía histórica de América Latina. Fuentes y métodos", en Rolando Mellafe, Historia social de Chile y América. Sugerencias y aproximaciones, Santiago, Editorial Universitaria, 1986, pp.146-176.

Dossier: Cuestionando las fuentes de archivos: padrones de población, familias y sociedades coloniales en Iberoamérica, ss. XVIII-XIX 
las recurrencias en este dato y sus variantes locales. Registrar qué, a quiénes y para qué en sí mismo es rotular, lo que he comprendido como una práctica social que se articula desde esquemas verbales o regímenes de imágenes operantes en los sujetos que registran o sus estructuras más generales de representación.

En ella se encuentran las tres formas predominantes de anotar la información: nombres y apellidos de hombres, mujeres y niños; estado (soltero, casado, viudo) y una tendencia a organizar el registro por cabezas de familia, cuestión coherente según lo señalado respecto a qué se entiende por calidad del sujeto. Una diferencia importante con los padrones mexicanos señalados es que no tiene a la "ciudad" como guía de los recorridos de quien registra, no son las calles ni las puertas su principal seña a seguir, sino que los habitantes por "casas" o unidades de residencia, jerarquía social (desde los "principales" en el siguiente orden según existan o no en la localidad: dueños de haciendas o trapiches, caciques de pueblos, dones y doñas, españoles) y la calidad de castas, concentrándose en españoles, mestizos, indios, negros y esclavos. De forma muy localizada, aparecen la denominaciones de mulatos, pardos, zambos y chinos. La Matrícula de Alday es un hermoso muestrario de todas las tradiciones cultivadas por los párrocos en las prácticas del registro, las nuevas y las antiguas, así como las personales. La tradicional forma de construir las matrículas en términos gráficos, por cuanto se repite para México, Lima y Chile, consistía en un cuadernillo a dos columnas ocupado por verso y reverso de la hoja, doblado por la mitad quedando un delgado librillo en que se iba anotando, en forma de lista, los nombres de cada habitante. Una variante material, es la del mismo cuadernillo, sin pliegue en medio.

Otra diferencia de la Matrícula de Alday con los padrones del Sagrario en México, es que el sacramento que ordena el registro es del matrimonio, no el de la confesión. Los criterios para ordenar los listados de españoles, indios, mestizos, y negros fueron casados, solteros, viudos y párvulos. Es muy interesante constatar que la mayor cantidad de notas aclaratorias se refiera a qué se entiende por estado de soltero. Por ejemplo, el registro de la doctrina de Llongocura explica que por solteros y solteras se entendía a "los que pasan de siete años sin otro estado diferente”. ${ }^{41}$ La excepcionalidad que representa esta Matrícula para Chile, la que por lo

\footnotetext{
${ }^{41}$ Matrícula de Alday, Archivo General de Indias (AGI), Audiencia Chile, 177, f.654. "Matrícula de la doctrina de Llongocura; en que se hallará todo el numero de feligreses de que se compone dicha doctrina; divididos por sus sexos; calidades y estados". Cura de la dicha doctrina $\mathrm{M}^{\mathrm{o}} \mathrm{Dn}$. Augustin
}

Dossier: Cuestionando las fuentes de archivos: padrones de población, familias y sociedades coloniales en Iberoamérica, ss. XVIII-XIX 
demás se encuentra en el Archivo general de Indias sin ningún documento anexo de contexto que explique su envío, ${ }^{42}$ me permite vincular la matrícula con la "Pragmática sanción para evitar el abuso de contraer matrimonios desiguales" promulgada por Carlos III el 23 de marzo de 1776, con extensión a todas las colonias americanas por Real Cédula de 7 de abril de 1778. Tanto los padrones del Sagrario como los encontrados en el Archivo Arzobispal de Lima -en el que se conservan padrones con cierta regularidad entre 1694 y 1880-, señalan que los párrocos en dichos lugares cumplieron con su obligación de manera más constante, cuestión que permite pensar que en los centros virreinales los controles eran imperiosos, en tanto se trata de ciudades populosas. Sin embargo, la Matrícula de Alday sólo cubre el Obispado de Santiago (el otro era el de Concepción), siguiendo tanto criterios de "corregimientos" como de "doctrinas", dos formas administrativas distintas. La fecha en que se ejecutó es relevante no sólo por la Pragmática de Matrimonios, sino también por la Real Orden de 8 de noviembre de 1776: "El Rey quiere saber con puntualidad y certeza el número de habitantes que tiene en todos los bastos dominios de América y Filipinas". ${ }^{43}$ Finalmente, no se debe olvidar que desde 1750, con fines de administración y conocimiento de los territorios, los Borbones retomaron con insistencia la solicitud de las relaciones geográficas y reportes sistemáticos sobre sus características. ${ }^{44}$

Antonio de Toro. Teniente de cura el $\mathrm{R}^{\mathrm{o}}$ Pe. Preceptor General fray Xacinto Cruz de Hermitaños de Nuestro Padre San Augustín.

42 Portada: Matrícula general de los vecinos del Reino de Chile, año 1778: "Chile años 1779. Varios testimonios de matriculas, recibidos en el Consejo en 1779 sin carta ni guia alguna". Nota: "Cartera antigua y casi destruida que este legajo se decia lo siguiente 'Chile= entre los [q]ue se abrieron en el Consejo el dia 6 de Diciembre de 1779 se [...] estos legajos de matriculas sin carta de acompañamiento alguna que manifieste el fin a que se remiten, por lo que [...] tenidos, hasta ver si se recibe la carta o guia con que dirigirse", AGI, Audiencia Chile, 177, f.1.

${ }^{43}$ AGI, Indiferentes 1527, referencia en Leticia Mayer Celis, "Los censos novohispanos a fines del siglo XVIII. Discusiones sobre inferencia estadística", ponencia presentada en el Congress of the Latin American Studies Association, Río de Janeiro, Brasil, junio 11-14 de 2009. Recurso electrónico www. lasa.international.pitt.edu/members/congress-papers/.../MayerLeticia.pdf, consultado el 8 de agosto de 2009.

44 Véase Francisco de Solano, Relaciones geográficas del Reino de Chile, 1756, Madrid, CSIC, 1995, p.19. También se cuenta para 1777 y 1778 con las descripciones de los Obispados de Santiago y Concepción, junto con las de Buenos Aires, Misiones del Uruguay, Asunción del Paraguay y Gran Chaco. Almanaques de Cosme Bueno, publicados en Lima 1768-1786, sin datos editoriales, Descripción del Obispado de Santiago de Chile, de 1777, ff.88-106 y Descripción del Obispado de Concepción, 1778, ff.131-154. 
Los censos tienen una genealogía diferente a la de las matrículas o padrones de confesión. Felipe II en 1575 ordenó en Castilla una encuesta a los "pueblos", llamada Relaciones Topográficas. Este esfuerzo de contar por sobre individualizar nombres, nos muestra las diferencias del recuento respecto del empadronamiento al estilo parroquial que "Son en realidad, fruto de un recordatorio incesante: el que hicieron los curas párrocos para machacarle a su feligresía la obligación del precepto de confesarse". ${ }^{45}$ Los conteos "totales" de población, o con ese ánimo, se dan en el XVIII. La experiencia censal puede tener un precedente importante en el catastro de España entre 1750 y 1756, gran proyecto que consideraba interrogatorios simultáneos, información del reconocimiento de las tierra, la confección de los libros de los cabezas de casa o de familias, relación completa de un vecindario en dos libros legos y eclesiásticos, con datos como nombre, estado civil, estamento, profesión, y edad del cabeza de familia y de su cónyuge, hijos, criados domésticos y de labor, aprendices y todo alojado en la casa del cabeza de familia. Los primeros intentos "serios" de conteo en el caso Español, fueron en la superintendencia de Aranda en 1768 y el de 1787 que se aplicó a América en 1790 aunque en ambas oportunidades, las distintas autoridades americanas contestaron en plazos diferentes, usaron diversos criterios para catalogar a la población y no siempre se ajustaron a la búsqueda de una misma información para todas las colonias. ${ }^{46}$ A este segundo proceso corresponde el conocido censo mexicano de 1790-1791 o censo de Juan Vicente Güemes Pacheco de Padilla Revillagigedo. ${ }^{47}$ Otras experiencias americanas se produjeron por cuestiones puntuales, pero asociadas más bien con las contribuciones e impuestos, por ejemplo, el censo de 1723 luego, el de 1738 para recolectar dinero

45 Óscar Mazín y Esteban Sánchez de Tagle, Los "padrones" de confesión y comunión de la parroquia del Sagrario Metropolitano de la ciudad de México, p.15.

${ }^{46}$ Eduardo Cavieres Figueroa, "Mestizaje y crecimiento de la población iberoamericana en el siglo XVIII", en Enrique Tandeter y Jorge Hidalgo (directores del volumen), Historia General de América Latina, vol.IV: Procesos americanos hacia la redefinición colonial, Madrid, Ediciones UNESCO/Editorial Trotta, 2000, pp.83-84.

47 Véase Leticia Mayer Celis, "Los censos novohispanos a fines del siglo XVIII. Discusiones sobre inferencia estadística", ponencia presentada en el Congress of the Latin American Studies Association, Río de Janeiro, Brasil, junio 11-14 de 2009. Recurso electrónico www. lasa.international.pitt.edu/members/congress-papers/.../MayerLeticia.pdf, consultado el 8 de agosto de 2009.

Dossier: Cuestionando las fuentes de archivos: padrones de población, familias y sociedades coloniales en Iberoamérica, ss. XVIII-XIX 
para la reconstrucción del palacio de Madrid consumido por el fuego ${ }^{48} \mathrm{o}$ el realizado entre 1725 y 1740 luego de la gran epidemia viruela en el Perú. ${ }^{49}$ Esta situación recurrente y constante aunque sus resultados no lo fuesen, fue claramente comprendida por la población víctima de tales medidas, la "plebe". Un documento conocido como censo de 1835 para Chile, pero en realidad es una investigación propia del autor recabando información compilada de un mandato de censo para el año 1831 que nunca se completó, señala que al menos el 10\% de la población (de un total de 1.010.336), "se sustrae del conocimiento de los comisionados para levantar los censos a causa de lo diseminado de la población y principalmente de que aun no ha podido destruirse la persuasión en que está la generalidad de la plebe de que dichos censos no tienen otro objeto que el de averiguar el número de hombres que puede reclutarse para el ejército o para imponerles alguna gabela". ${ }^{50}$

El Censo de 1813, efectivamente el primer censo de "territorio", levantado por Juan Egaña explica el objetivo del mismo, que el gobierno no puede disponer la felicidad pública sin "saberse el número de la población, las profesiones, y demás circunstancias de los ciudadanos con cálculos seguros ningún objeto de beneficencia pública, y mucho menos se puede dar a los pueblos aquella organización, y representación política, que corresponde a un sistema popular" ${ }^{51}$ Cuatro son las categorías de registro que este censo utiliza: estado "civil", edades, origen y castas, profesiones y casas de objeto público. El censo de 1813 tiene como eje el territorio y el "origen" de los que lo habitan en una primera gran división "los de aquí y los de afuera”: españoles americanos, españoles europeos, españoles asiáticos, canarios y africanos; europeos extranjeros y las castas (indios, mestizos, mulatos y negros). Es importante constatar, que entre este censo se continúa utilizando el concepto de castas y asociado al origen, mientras que en el de 1835 se hace la opción por el de plebe, políticamente más adecuado en el nuevo contexto político. No obstante, en

\footnotetext{
${ }^{48}$ Eduardo Cavieres Figueroa, "Mestizaje y crecimiento de la población iberoamericana en el siglo XVIII", pp.83-84.

49 Adrian Pearce, "El censo demográfico peruano 1725-1740”, en Paulo Drinot y Leo Garófalo (eds.), Más allá de la dominación y la resistencia. Estudios de historia peruana, siglos XVI-XX, Lima, Instituto de Estudios Peruanos, 2005, pp.136-180.

50 Fernando Urízar Garfias, Repertorio Chileno, año de 1835, Santiago de Chile, Imprenta Araucana, p.III, advertencia.

${ }^{51}$ Censo de 1813, edición de 1953, Orden de la Junta de Gobierno formada por los señores Pérez, Infante y Eyzaguirre, Santiago 31 de mayo de 1813, p.1.
}

Dossier: Cuestionando las fuentes de archivos: padrones de población, familias y sociedades coloniales en Iberoamérica, ss. XVIII-XIX 
los registros parroquiales, sólo en 1853 se elimina el registro en libros separados por castas. ${ }^{52}$

\section{Registrar mestizos: la pureza, la madre y el párroco}

"Si un Indio se casase con una Española, aunque esto sucede rara vez", decía Solórzano, también sería Español. Español e India, es mestizo. La madre teóricamente definía la casta pues ella es testimonio del origen del hijo. Veamos qué pasa en las partidas de bautismos de los libros de "castas" de la Parroquia El Sagrario de la Catedral de Santiago de Chile (Archivo del Arzobispado de Santiago), entre los años 16501810 escogiendo 9 libros (años 165o, 1670, 1690, 1710, 1730, 1750, 1770, 1790 y 1810). La revisión del material señala que en el transcurso más de un siglo y de una muestra de 1546 bautizados no hay ninguna regla a seguir por parte del párroco o de los padres, puesto que tampoco el registro permite aclarar quién decide el rótulo de la inscripción. Manejábamos dos hipótesis al respecto, la primera, que la calidad de "casta" es decir de persona proveniente de la mezcla de los llamados "españoles", con "indios" y "negros" y entre estos dos grupos, tenía un patrón de heredabilidad dada por la madre. Esto querría decir que tanto el ocultamiento de la calidad de casta como su exhibición dependían de la calidad de la progenitora. La segunda, decía que dicha calificación dependía del funcionario que estuviera a cargo del registro. Los libros de bautismos del Sagrario confirman la segunda opción, es decir, que la consignación de la calidad en los registros (más no la potencial relación entre la casta de la madre/padre para lo que se requiere de un estudio más amplio y eminentemente cualitativo). De ahí que los resultados obtenidos están sustancialmente distorsionados. Habría que transcribir todas las partidas de bautismo de castas, por ejemplo, de un mismo sacerdote (para lo cual sería bueno realizarlo en una parroquia periférica, El Sagrario, tuvo constantemente más de un sacerdote oficiando), de modo de poder establecer patrón de partida de bautismo y de traspaso de la calidad de casta al bautizado en un espacio y tiempo determinado.

\footnotetext{
52 Alejandra Araya Espinoza, "Imaginario socio-político e impresos modernos: de la plebe al pueblo en proclamas, panfletos y folletos. Chile 1812- 1823", en Fronteras de la Historia vol.16, n. ${ }^{\circ} 2$, Bogotá, ICANH, 2011, pp.297-326.
}

Dossier: Cuestionando las fuentes de archivos: padrones de población, familias y sociedades coloniales en Iberoamérica, ss. XVIII-XIX 
Igual tendencia se constata en la Matrícula de Alday, de la cual se escogieron tres matrículas (curatos de Ñuñoa, Lontué y Curicó) para este micronálisis por estar organizadas en función del lugar de habitación, ya fueren ranchos, casas, cuartos, estancias o localidades rurales. La elección partió de la premisa de que su estudio permitiría vislumbrar la convivencia entre castas en espacios cotidianos de habitación. Sin embargo, las matrículas no informan lo suficiente respecto de las unidades habitacionales, como tampoco respecto del tipo de relación entre las personas moradoras de cada una de estas unidades. Quienes hicieron estas matrículas, los curas Céspedes, Torres y Grez, al parecer intentaron limitarse al cómputo de personas por casta, estado civil y género. Si siguieron un orden por unidad habitacional se debió principalmente al carácter rural de estos tres curatos, a la probable imposibilidad que tuvieron los curas para reunir a su feligresía y así realizar un cómputo sincrónico, y por ende, a la necesidad de realizar un cómputo asociado a la visita de sus respectivas doctrinas. Esta muestra corrobora lo ya señalado respecto de la importancia de los agentes del registro en los criterios que rigen y organizan los documentos donde las "castas" aparecen. Algunas notas de los párrocos son fundamentales para considerar que se debe trabajar cualitativamente con estos registros, pues los resúmenes eliminan información relevante respecto de cómo organizarlos. Por ejemplo, el párroco del corregimiento de San Juan de la Provincia de Cuyo, remite su matrícula según las "instrucciones", pero ordena las listas de forma totalmente diferente a las tendencias esquemática de español, mestizo, indio, negros libres y esclavos. A la matrícula de españoles le sigue la de "mestisos, y mulatos libres" 53 y la "Matrícula de Indios y negros esclavos" 54 y la forma de la inscripción también es un buen ejemplo de la variabilidad del mismo según el escribiente que puede buscar su propio método para hacer más eficiente las sumas (con siglas $\mathrm{C}=$ casado o $\mathrm{E}=\mathrm{Español}), 55$ estrategias para apuntar más rápido los datos como "Gregorio Albarracin Indio casado con María negra esclava" o "Ambrosio Arguello soltero=Maria Ignacia mulatos libres”. Este párroco finaliza la matrícula con esta significativa nota:

\footnotetext{
${ }^{53}$ Matrícula de Alday, AGI, Audiencia Chile, 177, foja 935.

54 Matrícula de Alday, AGI, Audiencia Chile, 177, foja 956.

55 Un ejemplo: Matrícula de Alday, AGI, Audiencia Chile, 177, foja 495, Matrícula general del curato de Curicó. Marcas: Y.S.=Indio soltero; Mzo. C=mestizo casado.
}

Dossier: Cuestionando las fuentes de archivos: padrones de población, familias y sociedades coloniales en Iberoamérica, ss. XVIII-XIX 
Queda así concluida la Matricula general de toda la feligresía de esta ciudad de Sn. Juan conforme el método que ha sido remitido para su ejecución: advirtiéndose que el exceso que aparece de una mujer entre los cazados españoles les viene de no estar puesto en la suma de varones su marido por estar perdido, y no saberse su vive, o muere; y que los mulatos libres van comprendidos en el cuaderno de la Matricula de mestizos como también en el de esclavos los Indios de los que son muchos lo que se hallan cazados con negras; yendo de una a otra casta suma separada en la foja anterior , y para que conste en cumplimiento de lo mandado lo firme en esta dicha ciudad de Sn. Juan en veinte días de el mes de Noviembre de mil setecientos setenta y siete años. Andres Jofré. 56

El cura y vicario de la provincia de Limarí, Francisco Xavier Martínez, por otra parte, organiza la matrícula por listados alfabéticos de hombres y mujeres, casados, solteros y párvulos por castas. Quizás con una experiencia previa realiza el registro en ese orden en el momento mismo que anota, al punto que aparecen notas como estas "Mujeres españolas párvulas, digo solteras". ${ }^{57}$ En su matrícula también aparecen los únicos "mulatos zambos y cholos"58 e "indias encomenderas" la Matrícula de Alday y la interesante nota que indica la relación entre casta y pureza desde el imaginario de las mezclas al que ya aludí:

Indios puros libres no residen en esta doctrina, y aunque en otros tiempos los havria al presente se hallan mixtos con mulatos, y sambos, y se hallan reducidos a dichos gremios. Negros puros no se mencionan por no haberlos en toda la doctrina [...] Previenese que todo este numero de gentes mencionado no es permanente en la doctrina principalmente la gente minera por ser la dicha gente vaga que anda de lugar en lugar sin tener residencia, por lo que sucede que muchas veces se hallara en la doctrina este numero de gente, otras veses menos, y otras mas según el estado de las minas lo que declara para que conste, y certifico yo el presente cura, y vicario de la Doctrina de Limari ser esta la matricula legal, y verdadera de dicha doctrina, la que se a practicado, y hecho con toda prolijidad, y cuidado para que vaya conforme, y según se pide, y para que

\footnotetext{
${ }^{56}$ Matrícula de Alday, AGI, Audiencia Chile, 177, foja 966.

${ }^{57}$ Matrícula de Alday, AGI, Audiencia Chile, 177, f.345v.

58 Matrícula de Alday, AGI, Audiencia Chile, 177, ff.329 y ss.

${ }^{59}$ Matrícula de Alday, AGI, Audiencia Chile, 177, f.344.
} 
conste asi lo certifico, y firmo en dicha doctrina en 10 de noviembre de 1777 , Francisci Xavier Martinez. ${ }^{60}$

La "domesticidad" de las matrículas y la relación de los párrocos con sus habitantes también se trasluce en la forma de registrar, si en Santiago capital la huella de la relación personal es casi imperceptible por "populosa" en relación a las zonas "rurales", en la "Matrícula exacta de la Gente del Curato de Sotaquí Jurisdicción de la Serena de Chille, a cargo del Dr. Dn Gaspar Reynaldo fecha en 15 de julio de 1777 años" la familiaridad y el lenguaje menos formal es notable pues mujeres y hombres fueron registrado como "chicos y grandes" y los grupos agrupados en familias casi como un relato:

Pedro Duran viudo sus hijos varones Juan, y Francisco y [Joseph] párvulo, sus hijas Michaela, Geronyma y Cayetana solteras que son 2 solteros, 1 párvulo y 3 solteras

Don Gabriel Pisarro, casado con Doña Andrea Rojas-

Juan Agustín Pisarro casado, con Manuela Pisarro, tiene una hija párvula maría Agustina

Lasaro Toro casado con Manuela Ardiles, mestisa, tienen sinco hijas solteras, que son Dolores, candelaria; y dos varones Jph y Jph Miguel, parvulos, son 2. ${ }^{61}$

Y en esta misma matrícula regresamos a la cuestión de la madre y las variables -todavía por estudiar- de la heredabilidad de las castas según las tradiciones culturales de los grupos homogeneizados bajo el rótulo de "indios" pero diferentes entre sí. ${ }^{62}$ En la foja 308 y 310 respectivamente, encontramos estos registros pertenecientes a la matrícula de españoles: "Nicolas Niño de Zepeda casado con Petrona

\footnotetext{
${ }^{60}$ Esta nota también nos informa que la revisión y organización final de la matrícula, paso al que corresponde la nota, se realiza tres meses después de haber hecho el recorrido por los lugares pues las matrículas por castas se realizaron durante el mes de agosto de 1777. Matrícula de Alday, AGI, Audiencia Chile, 177, ff.345-346.

${ }^{61}$ Matrícula de Alday, AGI, Audiencia Chile, 177, f.307.

62 Esta cuestión es central desde la conquista temprana, véase Berta Ares, "Mancebas de españoles, madres de mestizos. Imágenes de la mujer indígena en el Perú colonial temprano", en Pilar Gonzalbo Aizpuru y Berta Ares Queija (eds.), Las mujeres en la construcción de las sociedades iberoamericanas, Sevilla/México, Escuela de Estudios Hispanoamericanos/El Colegio de México, 2004, pp.15-39.
} 
Guatemanque india libre, sus hijos son mestisos y se pondran en su lugar [...]" "Juan Delgado casado con loreta Geres mulata, sus hijos se pondrán en su lugar".

La pregunta sería ¿cuál es ese lugar?, el de los mestizos en el primer caso y de los mulatos en el segundo. Podríamos decir que, en este caso, la madre efectivamente define que los hijos no sean reconocidos como españoles y que el padre "contiene" el no sean consignados en las castas asociadas a la descendencia de los negros, situación a la que no puede contribuir la madre. Esto se corrobora al revisar "la matrícula de negros y mulatos esclavos, y libres" del mismo registro citado en el cual las indias libres quedan consignadas como mulatas al estar casadas con mulatos y negros, no importando si son libres o esclavos. "Fin de la matricula de mulatos":

Juan Aranda mulato libre casado. Rosa Cortes Mestisa, sus hijos Enrique, Simon, Antonia Rosa, solteros, Maria, Loreta, Manuel, párvulos

"Hernando Sandoval negro libre, casado con Francisca Contulien, yndia libre, sus hijos, Maria soltera, y sus hijos Jph, Juan, solteros

Felisiana Pisarro mulata esclava casada con Ramón linares mestiso, sus hijos, francisco, Phelipe, Santos, Mria, Rosalia, solteros

Miguel Muños, viudo, mulato libre, su hijo mariano soltero

Mateo Vargas negro esclavo casado con Nicolasa Ladino, yndia encomendera

Rita Rojas mulata esclava casada con Ramón Pasten mestiso, sus hijos Maria, Anastacia, parvulos, Tomas Rojas mulato esclavo soltero

Bernardo Araya mulato libre soltero Ynes Cortés, negra esclava casada con

Martin Calavasero Yndio libre ${ }^{63}$

\section{Una historia para el final}

A lo largo del texto he reiterado de forma suficiente los planteamientos respecto de las denominaciones de casta como prácticas sociales coloniales, la reescritura y la invención de una nueva sociedad. También creo haber sugerido de manera clara los aportes que una historia de las mentalidades y en particular desde los imaginarios, al trabajo con diversos registros y en especial el de las matrículas y padrones otorgándoles un lugar significativo en esa escritura de las castas especialmente si ponemos atención a su carácter eminentemente cualitativo. Quisiera terminar con

${ }^{63}$ Matrícula de Alday, AGI, Audiencia Chile, 177, ff.318-320.

Dossier: Cuestionando las fuentes de archivos: padrones de población, familias y sociedades coloniales en Iberoamérica, ss. XVIII-XIX 
esta dimensión, por cuanto la trayectoria del uso de tales documentos esto es, hacia lo estadístico, le dio a su carácter poco "preciso" en términos de datos y de confusos precisamente por la variabilidad de la asignación de las denominaciones según tiempo y lugar. Lo que yo señalo es que esas características son las que permiten dar cuenta del lugar problemático y central de la llamada cuestión de las castas americanas en el imaginario social de esa nueva sociedad llamada colonial. Cuando el párroco consigna de manera tan diversa es justamente porque el fenómeno lo fue, porque la comprensión de la situación de mezcla se leyó desde la lógica de la variación y la diversidad. Hay que seguir trabajando en la sistematización de los repertorios y autores justamente para poder identificar las regularidades y las disrupciones, los aportes y las diferencias teóricas del pensamiento americano sobre sí mismo respecto de los autores circulantes en un mundo ya global para los siglos XVII y XVIII. Es esto también de lo que da cuenta la denominación de criollo y de mestizo en su variante americana más que desde la hibridez de las teorías científicas de la época. Es decir, la pregunta, la duda, la reflexión que implica decirse natural o identificarse desde una calidad. Son pocos los textos de personas de castas, comunes y corrientes, que nos informen sobre cómo comprenden su calidad. Ojalá tuviéramos más confesiones como las de Julián Santos quien frente a esas preguntas, dice ser "natural de partido de Maule" y de calidad "mestizo por ser hijo de mestizo y de mujer española" aunque todos los testigos se refieren a él como indio. ${ }^{64}$ La polivalencia de los términos y sus usos estratégicos está “probado" en la historiografía contemporánea justamente por lo que se gana y pierde al denominarse de una u otra cosa. En el caso de Julián, asumirse indio finalmente significó tener defensa aunque también poner en marcha una serie de estereotipos operantes en su momento respecto de la ociosidad y los vicios por ser tal, especialmente si era peón de arria que se ganaba la vida también como cantor y guitarrero. ${ }^{65}$ Julián tiene una historia afectiva con una mujer cuya madre defiende su honor y calidad de española y decente para poder casarla, ellos se fugaron y el proceso inicia meses

\footnotetext{
64 "Petronila Zúñiga contra Julián Santos por rapto de Antonia Valenzuela su hija”, Archivo Histórico Nacional de Chile, Fondo Real Audiencia, vol.1957, pieza $5^{\mathrm{a}}$, 1720-1721. Confesión de Julián Santos, 2 de octubre de 1720, f.233.

${ }^{65} \mathrm{Su}$ caso me es especialmente querido porque me permitió desarrollar una serie de propuestas respecto del carácter textual y narrativo de las causas judiciales. Alejandra Araya, "Petronila Zúñiga contra Julián Santos por estupro, rapto y extracción de Antonia Valenzuela, su hija [...] el uso de los textos judiciales en el problema de la identidad como problema de sujetos históricos", en Anuario de Postgrado n. $^{\circ}$, Santiago, Universidad de Chile, 1999, pp.219-241.
}

Dossier: Cuestionando las fuentes de archivos: padrones de población, familias y sociedades coloniales en Iberoamérica, ss. XVIII-XIX 
después del hecho cuando son capturados. Las diferencias de calidad articulan historias personales que creo son importantes de relevar, es por eso también que he dejado los nombres de todos ellos pues esa riqueza de los padrones ha sido borrada por el afán de darles un lugar cuantitativo y estadístico y he hablado de narraciones respecto de su forma. Recordemos la frase "se pondrá en su lugar", ese es el capítulo en la historia personal de unos sujetos y de un grupo. Y la experiencia es en todas direcciones y para todos los sujetos, es justamente la experiencia personal, expresada también en los autores del periodo citados, la que me parece más relevante que su dimensión informativa o documental respecto a cómo comprender una denominación. Tanto para el Inca Garcilaso, como para Solórzano Pereira o el tan estudiado Huamán Poma de Ayala, la experiencia de estas tierras es la que define su lugar de enunciación, sus temas y sus posturas. Así como Julián a inicios del siglo XVIII en los confines del imperio, un sujeto metropolitano, padecía las mismas congojas del "lugar" al que obligaba la calidad a fines de la misma centuria. Decía Francisco Arias de Saavedra y Sangronis (Sevilla 1746-1819), Ministro de Hacienda de Carlos IV, en sus cuadernos personales, y hablando de su deseo de casarse con Manuelita una criolla de la Habana:

De lo que sí no puedo desentenderme es de la calidad. Yo estoy constituido en un empleo visible, mis gentes han nacido con algún honor; espero de un día a otro una gracia de hábito de Carlos III, mi mujer se debería presentar en la Corte alternando con gentes distinguidas, por consiguiente me sería muy doloroso que tuviese la menor tacha. Además, necesito pedir licencia al rey para casarme, y presentar papeles que justifiquen su calidad. La Habana, 26 de septiembre de 1781.66

Y en carta de 23 de octubre de 1781, confesaba querer hacer lo mismo que Julián -que se fugó con Antonia, que la raptó según la madre- con ciertos matices:

Era pues mi proyecto, casarme con ella en secreto, llevármela a Europa sola sin madre ni pariente alguno; tenerla cuatro o cinco meses en Francia en casa de un amigo mío, amoldándose a los usos y costumbres de por allá; pedir mientras tanto licencia al Rey para ponerme en estado, presentarla como una americana

\footnotetext{
${ }^{66}$ Manuel Moreno Alonso, Memorias inéditas de un ministro ilustrado, Editorial Castillejo, Sevilla, 1992. Correspondencia con Manuel Fernández de Lara, administrador de Rentas en el puerto de Trinidad de la isla de Cuba, donde llegó en enero de 1781, desde Jamaica, p.183.
}

Dossier: Cuestionando las fuentes de archivos: padrones de población, familias y sociedades coloniales en Iberoamérica, ss. XVIII-XIX 
pobre pero bien nacida a quien me había inclinado el puro mérito sin mezcla de interés ni vanidad". 67

Tanto Julián como Francisco formaban parte de un mundo cultural cuya mentalidad fijaban y anclaban las posibilidades personales a las identidades grupales. Julián no tuvo muchas opciones para defenderse, su protector ataca entonces el argumento de la madre, la honra de la hija. Es decir, no era tan honrada como decía y eso podría salvar a Julián de la acusación de rapto y estupro. La desigualdad de calidades o la calidad, para la madre, era su capital social. Claramente para el "indio" o el "mestizo" tales cuestiones eran más difíciles de defender por desconfianza natural. Francisco, por su parte, ya a fines del siglo XVIII expresa justamente la visibilización de un sentir privado respecto de la voluntad individual y los méritos de la honra libres de la calidad, pero no era posible en su posición como tampoco por los imaginarios operantes sobre los habitantes americanos: “...A pesar de las consideraciones de mi razón cuando estaba un poco tranquila hice los últimos esfuerzos en la Corte para ver si casarme con ella. La Manolita es muy buena y bien nacida aunque pobre: pero Vm., sabe con qué repugnancia se miran por acá los casamientos con las criollas. Han dado la desgracia que La Habana se acaban de hacer algunos matrimonios desiguales y esto ha empeorado la cosa". 68

\footnotetext{
${ }^{67}$ Manuel Moreno Alonso, Memorias inéditas de un ministro ilustrado, p.185.

68 Manuel Moreno Alonso, Memorias inéditas de un ministro ilustrado, pp.187-188.
} 


\section{Bibliografía}

\section{Fuentes primarias}

Archivo General de Indias (Sevilla, España), (AGI).

Archivo del Arzobispado de Santiago

\section{Fuentes primarias impresas}

Bueno, Cosme, Almanaques de Cosme Bueno. Lima, sin datos editoriales. Ejemplar del Archivo Central Andrés Bello de la Universidad de Chile, 17681786.

Censo de 1813. Levantado por don Juan Egaña, de orden de la Junta de Gobierno formada por los señores Pérez, Infante y Eyzaguirre, Santiago, Imprenta de Chile.

Covarrubias, Sebastián de. Tesoro de la lengua castellana o española, ed. Felipe C. R. Maldonado. Madrid, Castalia, 1995 [1611].

Garcilaso de la Vega, Inca, Comentarios reales de los incas, ed. Carlos Araníbar. Tomos I y II, México, Fondo de Cultura Económica, 1991 [1609].

Molina, Juan Ignacio, Compendio de la historia civil del Reyno de Chile. Parte Segunda. Traducida al español, y aumentada con varias notas por Nicolás de la Cruz y Bahamonde, Madrid, Imprenta de Sancha. Edición facsimilar Biblioteca del Bicentenario, Santiago, Pehuén Ltda., 2000 [1788].

Manuel Moreno Alonso, Memorias inéditas de un ministro ilustrado, Sevilla, Editorial Castillejo, 1992.

Solano, Francisco de (ed.), Cuestionario para la formación de las Relaciones Geográficas de Indias, siglos XVI/XIX. Madrid, Consejo Superior de Investigaciones Científicas, 1988.

Solano, Francisco de, Relaciones geográficas del Reino de Chile. Madrid, Santiago de Chile, Consejo Superior de Investigaciones Científicas, Universidad Internacional SEK, 1995 [1756]. 
Solórzano Pereira, Juan de, Política Indiana. Dividida en seis libros, en los cuales con gran distinción; y estudio se trata, y se resuelve todo lo tocante al descubrimiento, Madrid, Gabriel Ramírez, 1736-1739.

Urízar Garfias, Fernando, Repertorio Chileno, año de 1835, Santiago de Chile, Imprenta Araucana.

\section{Fuentes secundarias}

Amador Bech, Julio, Las raíces mitológicas del imaginario político, México, Universidad Nacional Autónoma de México/Miguel Ángel Porrúa, 2004.

Anrup, Roland y Chávez, María Eugenia. "La «plebe» en una sociedad de «todos los colores». La construcción de un imaginario social y político en la colonia tardía en Cartagena y Guayaquil" en Caravelle n. ${ }^{\circ} 84$, Tolousse, 2005, pp.93-126.

Apolant, Juan Alejandro, "Padrones olvidados de Montevideo del siglo XVIII. III al VII, con dos anexos", separata ampliada del Boletín histórico del Estado Mayor del Ejército, Montevideo, 1968.

Ares Queija, Berta. Mestizos, mulatos y zambaigos (Virreinato del Perú, siglo XVI)”, en Berta Ares y Alejandro Stella (eds.), Negros, mulatos, zambaigos. Derroteros africanos en los mundos ibéricos, Sevilla, Escuela de Estudios Hispano-Americanos, 2000, pp.75-88.

Ares Queija, Berta, Mancebas de españoles, madres de mestizos. Imágenes de la mujer indígena en el Perú colonial temprano. En Las mujeres en la construcción de las sociedades iberoamericanas, eds. Pilar Gonzalbo Aizpuru y Berta Ares Queija, 15-39. Sevilla/México, Escuela de Estudios Hispanoamericanos, El Colegio de México, 2004.

Araya Espinoza, Alejandra, Ociosos, vagabundos y malentretenidos en Chile colonial, Santiago, Centro de Investigaciones Diego Barros Arana/LOM, 1999.

Araya Espinoza, Alejandra, "Petronila Zúñiga contra Julián Santos por estupro, rapto y extracción de Antonia Valenzuela, su hija...el uso de los textos judiciales en el problema de la identidad como problema de sujetos históricos", en: Anuario de Postgrado $\mathrm{N}^{\circ}$ 3, Facultad de Filosofía y Humanidades, Universidad de Chile, Santiago, junio 1999, pp. 219-241. 
Araya Espinoza, Alejandra, "La Matrícula de Alday (1777-1778): imaginarios sociales y políticos en el siglo XVIII americano", en América a debate. Revista de Ciencias Históricas y Sociales n. ${ }^{\circ} 16$, Morelia, Universidad de Michoacán, 2009, pp.11-33.

Araya Espinoza, Alejandra, "Registrar a la plebe o el color de las castas: 'Calidad', 'clase' y 'casta' en la matrícula de Alday (Chile, siglo XVIII), en Alejandra Araya/Jaime Valenzuela (eds.), Denominaciones, clasificaciones e identidades en América colonial, Santiago, Fondo de Publicaciones Americanistas Universidad de Chile/Pontificia Universidad Católica de Chile/RIL Editores, 2010, pp.331-361

Araya Espinoza, Alejandra, "Imaginario socio-político e impresos modernos: de la plebe al pueblo en proclamas, panfletos y folletos. Chile 1812- 1823", en Fronteras de la Historia vol.16, n. ${ }^{\circ}$ 2, Bogotá, ICANH, 2011, pp.297-326.

Araya Espinoza, Alejandra, “¿Castas o razas?: imaginario sociopolítico y cuerpos mezclados en la América colonial. Una propuesta desde los cuadros de castas, pp.53-73, en Hilderman Cardona/Zandra Pedraza (comps.), Al otro lado del cuerpo. Estudios biopolíticos en América Latina, Bogotá, Universidad de los Andes/Sello Editorial Universidad de Medellín, 2014, pp.

Alvar, Manuel, Léxico de mestizaje en Hispanoamérica, Madrid, Ediciones Cultura Hispánica, 1987.

Bernand, Carmen, "Híbridos en Hispanoamérica. Un enfoque antropológico de un proceso histórico", en Guillaume Boccara/Sylvia Galindo (eds.), Lógicas mestizas, Temuco-Chile, Instituto de Estudios Indígenas Universidad de la Frontera, 1999, pp.61-84.

Bernand, Carmen, "Mestizos, mulatos y ladinos en Hispanoamérica: un enfoque antropológico de un proceso histórico", en Miguel León Portilla (coord.), Motivos de la antropología americanista. Indagaciones en la diferencia, México, Fondo de Cultura Económica, 2001, pp.105-133.

Bernand, Carmen, De lo étnico a lo popular: circulaciones, mezclas, rupturas. En Nuevo Mundo Mundos Nuevos [En línea], Debates, puesto en línea el 18 de enero de 2006. http://nuevomundo.revues.org

Boccara, Guillaume, "Antropología diacrónica, dinámicas culturales, procesos históricos y poder político”, en Guillaume Boccara/Sylvia Galindo (eds.), Ló-

Dossier: Cuestionando las fuentes de archivos: padrones de población, familias y sociedades coloniales en Iberoamérica, sS. XVIII-XIX 
gicas mestizas, Temuco-Chile, Instituto de Estudios Indígenas Universidad de la Frontera, 1999, pp.21-59.

Camba, Úrsula, Imaginarios ambiguos, realidades contradictorias: conductas y representaciones de los negros, mulatos y novohispanos. Siglos XVI y XVII, México, El Colegio de México, 2008.

Carmagnani, Marcello y Klein, Herbert, "Demografía histórica: la población del Obispado de Santiago, 1777-1778", en Boletín de la Academia Chilena de la Historia n. $^{\circ}$ 72, Santiago, Academia Chilena de la Historia, 1965, pp.57-74.

Castillo, Norma, "Matrimonios mixtos y cruce de la barrera del color como vías para el mestizaje de la población negra y mulata (1674-1796)", en Signos Históricos vol.II, n. ${ }^{\circ}$ 4, México, UAM-Iztapalapa, 2000, pp.107-137.

Cavieres, Eduardo, "Formas de vida y estructuras demográficas de una sociedad colonial: San Felipe en la segunda mitad del siglo XvIII", en Cuadernos de Historia $\mathrm{n}^{\circ}{ }^{\circ}$, Santiago, 1983, pp.79-97.

Cavieres, Eduardo, "Población y sociedad: avances de la demografía histórica en Chile (a propósito de dos recientes publicaciones)", en Cuadernos de Historia . $^{\circ}$ 5, Santiago, 1983, pp.105-120.

Cavieres Figueroa, Eduardo, "Mestizaje y crecimiento de la población iberoamericana en el siglo XVIII", Enrique Tandeter y Jorge Hidalgo (directores del volumen), Historia General de América Latina, vol.IV: Procesos americanos hacia la redefinición colonial, Madrid, Ediciones UNESCO/Editorial Trotta, 2000, pp.83-84.

Cuadra, Guillermo de la, "Censo de la Capitanía General de Chile en 1777", en Boletín de la Academia Chilena de la Historia n. ${ }^{\circ} 12$, Santiago, Academia Chilena de la Historia, 1940, pp.85-132.

Gilbert Durand, La imaginación simbólica, Buenos Aires, Amorrortu Editores, 1971.

Durand, Gilbert, Las estructuras antropológicas del imaginario, México, Fondo de Cultura Económica, 2002.

Estenssoro, Juan, "Los colores de la plebe: razón y mestizaje en el Perú colonial”, en Natalia Majluj (ed.), Los cuadros del mestizaje del virrey Amat. La re-

Dossier: Cuestionando las fuentes de archivos: padrones de población, familias y sociedades coloniales en Iberoamérica, ss. XVIII-XIX 
presentación etnográfica en el Perú colonial, Lima, Museo de arte de Lima, 2000, pp.66-107.

García Saíz, María Concepción, Las castas mexicanas: un género pictórico americano. Milán/México, Olivetti, 1989.

García Saíz, María Concepción. "Introducción”, en Un arte nuevo para un Nuevo Mundo. La colección virreinal del Museo de América de Madrid en Bogotá, Madrid, Museo de América, 2004, pp.17-37.

Katzew, Ilona, La pintura de castas. Representaciones sociales en el México del siglo XVIII: México/Madrid, Yale University Press/Turner/Conaculta, 2007.

Konetzke, Richard, "Los mestizos en la legislación colonial”, en Revista de Estudios Políticos n ${ }^{0} 112$, Madrid, 1960, pp.113-148.

Lipschutz, Alejandro, El problema racial en la conquista de América y el mestizaje, Santiago, Editora Austral, 1963.

López Beltrán, Carlos, "Sangre y temperamento. Pureza y mestizajes en las sociedades de castas americanas", en Frida Gorbuch y Carlos López, Michoacán (eds.), Saberes locales: ensayos sobre historia de la ciencia en América Latina, El Colegio de Michoacán, 2008, pp.289-342.

Mayer Celis, Leticia "Los censos novohispanos a fines del siglo XvIII. Discusiones sobre inferencia estadística", ponencia presentada en el Congress of the Latin American Studies Association, Río de Janeiro, Brasil, junio 11-14 de 2009. Recurso electrónico www.lasa.international.pitt.edu/members/congresspapers/.../MayerLeticia.pdf, consultado el 8 de agosto de 2009.

Martínez, José Luis, "Construyendo mundos: el "nacimiento" de los indios en los Andes del siglo XVI”, en Alejandra Araya, Azún Candina y Celia Cussen (eds.), Del Nuevo al Viejo Mundo: mentalidades y representaciones desde América, Santiago, Universidad de Chile, 2007, pp.23-34.

Mazín, Óscar y Sánchez de Tagle, Esteban (coords.), Los "padrones" de confesión y comunión de la parroquia del Sagrario Metropolitano de la ciudad de México, México, El Colegio de México/Red Columnaria, 2009. 
Mellafe, Rolando, "Demografía histórica de América Latina. Fuentes y métodos", en Rolando Mellafe, Historia social de Chile y América. Sugerencias y aproximaciones, Santiago, Editorial Universitaria, 1986, pp.146-215.

Mellafe, Rolando / Loyola, Lorena, "El tiempo, la edad, la vejez", en Rolando Mellafe/Lorena Loyola, La memoria de América colonial, Santiago, Editorial Universitaria, 1994, pp.33-55.

Millones, Luis, "Filosofía e historia natural en el Inca Garcilaso", Biblioteca Virtual Miguel de Cervantes, consultado en línea el 23/12/2010.

Mörner, Magnus, La mezcla de razas en la historia de América Latina, Buenos Aires, Paidós, 1969.

O’Toole, Rachel Sarah, "Castas y representación en Trujillo colonial”, en Paulo Drinot y Leo Garófalo (eds.), Más allá de la dominación y la resistencia. Estudios de historia peruana, siglos XVI-XX, Lima, Instituto de Estudios Peruanos, 2005, pp.48-76.

Pearce, Adrian, "El censo demográfico peruano 1725-1740", en Paulo Drinot y Leo Garófalo (eds.), Más allá de la dominación y la resistencia. Estudios de historia peruana, siglos XVI-XX, Lima, Instituto de Estudios Peruanos, 2005, pp.136-180.

Pino, Fermín del, "Historia natural y razas humanas en los 'cuadros de castas' hispano-americanos, en Frutas y castas ilustradas, catálogo de la exposición Museo de Antropología, 25 de febrero-29 de agosto de 2004. Madrid, Ministerio de Educación, Cultura y Deporte, 2004, pp.47-66.

Rodríguez, Lorena, "Repensando las clasificaciones socio-étnicas del siglo XVIII. Indios, mestizos y españoles al sur del valle Calchaquí (Argentina)”, en Fronteras de la Historia vol.13, n. ${ }^{\circ}$ 2, Bogotá, ICANH, 2008, pp.305-323.

Romero de Tejada, Pilar, "Los cuadros del mestizaje del virrey Amat", en Natalia Majluf (ed.), Los cuadros del mestizaje del Virrey Amat. La representación etnográfica en el Perú colonial, Lima, Museo del Arte, 200o, pp.1647.

Solano, Sergio Paolo, "Repensando la configuración socio-racial del Nuevo Reino de Granada, siglo XVIII: pardos, mulatos, cuarterones y quinterones", en 
Aguaita n. ${ }^{\circ}$ 25, Cartagena, Observatorio del Caribe Colombiano, 2013, pp.39-59.

Solano, Sergio Paolo, "Padrones de población e historiografía sobre la configuración socio-racial hispanoamericana del siglo XVIII", en El Taller de la Historia vol.5, n. $^{\circ}$, Cartagena, Universidad de Cartagena, 2013, pp.125-177.

Stolcke, Verena, "Los mestizos no nacen, se hacen", en Verena Stolcke y Alexandre Coello (eds.),Identidades ambivalentes en América Latina (siglos XVI-XX), Barcelona, Edicion Bellaterra, 2008, pp.19-58. 